\section{AB0789 APPLICATIONS OF LOW-FIELD MAGNETIC RESONANCE IMAGING IN A RHEUMATOLOGY DEPARTMENT}

I. M. Fernández-Maeztu Palacín ${ }^{1}$, D. Ruiz-Montesinos ${ }^{1}$, P. Muñoz Reinoso ${ }^{1}$ G. Jurado Quijano ${ }^{1}$, J. J. Pérez Venegas ${ }^{1}$, L. Fernández de la Fuente Bursón ${ }^{1}$.

${ }^{1}$ Hospital Universitario Virgen Macarena, Rheumatology, Sevilla, Spain

Background: Low-field MRI (LF-MRI) is a useful Imaging technique for the diagnosis and in the follow-up of high-impact rheumatologic pathology ${ }^{1}$. However, the use of the Low-field MRI is not widespread due to the high cost and the use of other techniques such as Musculoskeletal sonography ${ }^{2}$. The Rheumatology Unit of the HUVM owns a Musculoskeletal Imaging Unit (ECO /MRI) and a standardized protocol for LF-MRI ${ }^{3}$, which is performed by a rheumatologist applied in a routine clinical practice. We describe the patterns of use of LF-MRI by general rheumatologists in their routine clinical practice.

Objectives: Perform an analysis of the use of LF-MRI in a Rheumatology department to the assessment of joint inflammatory activity. Correlate the results of the analyses in patients without diagnosis or patients with unclear diagnosis.

Methods: Retrospective analysis using the medical records of the patients referred to the Musculoskeletal Imaging Unit from January to June 2018. The main variables collected were reason for referral as well as previous and final diagnosis after LR-MRI. An evaluation on the usefulness of MRI is made twelve months later to establish the diagnosis.

Results: The global population studied of 114 patients were referred to for LF-MRI. 81 females (71\%). The $80 \%$ of the patients with previous diagnostic $40 \%$ Rheumatoid Arthritis (RA), 24\% Psoriatic Arthritis (PAs), 16\% other rheumatic diseases, and the remaining $20 \%$ with an unclear diagnosis. The most frequent reasons for referral were: 1) A total of patients (female and male) was referred to assessment of inflammatory activity prior to the change of treatment and 2) assessment of subclinical activity in patients with optimized treatment. A total of 23 patients ( 16 female; 7 male), were referred for diagnostic evaluation or differential diagnosis: 7 arthralgias, 6 suspected psoriatic arthritis, 6 with undiagnosed joint inflammation, 2 for differential diagnosis, 1 suspected of juvenile idiopathic arthritis (JIA), and 1 tendinitis. (Table 1 )

Table 1. Undiagnosed patients. Post-imaging diagnosis.

\begin{tabular}{|c|c|c|c|c|c|c|c|c|c|c|c|c|c|}
\hline & $\begin{array}{l}\text { TENO } \\
\text { SYNO- } \\
\text { VITIS }\end{array}$ & $\begin{array}{l}\text { NO } \\
\text { DIAG }\end{array}$ & & $\begin{array}{l}\text { MONO } \\
\text { ART- } \\
\text { HRITIS }\end{array}$ & $O A$ & $\begin{array}{l}\text { CARPAL } \\
\text { TUNNEL }\end{array}$ & $\begin{array}{l}\text { RULE } \\
\text { OUT } \\
\text { PAs }\end{array}$ & GOUT & SpA & $\begin{array}{l}\text { PLAN- } \\
\text { TAR } \\
\text { FASCII- } \\
\text { TIS }\end{array}$ & & PAs & $\begin{array}{c}\text { OS } \\
\text { TRI- } \\
\text { GO- } \\
\text { NUM }\end{array}$ \\
\hline ARTHRALGIAS & 1 & 1 & 1 & 0 & 0 & 1 & 0 & 2 & 0 & 1 & 0 & 0 & 0 \\
\hline $\begin{array}{l}\text { SWOLLEN } \\
\text { JOINT } \\
\text { WITHOUT } \\
\text { DIAGNOSIS }\end{array}$ & 0 & 1 & 1 & 1 & 2 & 0 & 0 & 0 & 0 & 0 & 0 & 0 & 1 \\
\hline $\begin{array}{c}\text { DIFFERENTIAL } \\
\text { DIAGNOSIS }\end{array}$ & 0 & 0 & 1 & 0 & 1 & 0 & 0 & 0 & 0 & 0 & 0 & 0 & 0 \\
\hline $\begin{array}{l}\text { SUSPECTED } \\
\text { PAs }\end{array}$ & 0 & 2 & 1 & 0 & 0 & 0 & 1 & 0 & 1 & 0 & 0 & 1 & 0 \\
\hline $\begin{array}{l}\text { SUSPECTED } \\
\text { JIA }\end{array}$ & 0 & 0 & 0 & 0 & 0 & 0 & 0 & 0 & 0 & 0 & 1 & 0 & 0 \\
\hline $\begin{array}{l}\text { TENDINITIS } \\
\text { WITHOUT } \\
\text { DIAGNOSIS }\end{array}$ & 1 & 0 & 0 & 0 & 0 & 0 & 0 & 0 & 0 & 0 & 0 & 0 & 0 \\
\hline Total & 2 & 4 & 4 & 1 & 3 & 1 & 1 & 2 & 1 & 1 & 1 & 1 & 1 \\
\hline
\end{tabular}

Conclusion: The results of our study shown that the addition of the LF-MRI into clinical practice and performed by a rheumatologist is a useful tool in the diagnosis and evaluation of the degree of disease activity in patients with joint inflammatory pathology. The main test-indication of these techniques is to assess the degree of activity of the disease. In a $20 \%$ of the cases, the LF-MRI was requested for diagnostic evaluation in patients without a clear diagnosis. The long-term follow-up studies that correlate symptoms with structural damage are necessary to define remission more accurately and evaluate the efficiency of different treatment options. REFERENCES:

[1] Hunt L, Eugénio G, Grainger AJ. Magnetic resonance imaging in individuals at risk of rheumatoid arthritis. Best Pract Res Clin Rheumatol. 2017 Feb;31(1):80-9.

[2] Mandl P, Ciechomska A, Terslev L, Baraliakos X, Conaghan PG, D'Agostino $\mathrm{MA}$, et al. Implementation and role of modern musculoskeletal imaging in rheumatological practice in member countries of EULAR. RMD Open. 2019 Jun 25;5(2):e000950.

[3] Gorbachova T, Melenevsky Y, Cohen M, Cerniglia BW. Osteochondral Lesions of the Knee: Differentiating the Most Common Entities at MRI. Radiographics. 2018 Sep-Oct;38(5):1478-95.

Disclosure of Interests: None declared

DOI: 10.1136/annrheumdis-2021-eular.1444

\section{AB0790 ULTRASOUND-GUIDED VERSUS ANATOMICAL LANDMARK INJECTION OF THE SHOULDER JOINT; A RETROSPECTIVE STUDY}

A. Radwan', A. Elsaman' ${ }^{1}$ 'Sohag University Hospital, Rheumatology and Rehabilitation, Sohag, Egypt

Background: Ultrasound is a widely used tool for diagnostic and interventiona purposes for a myriad of musculoskeletal conditions. The question about the value of ultrasound-guided injection over blind injection is debatable [1, 2].

Objectives: To test the value of ultrasound-guided injection versus blind subacromial-subdeltoid bursitis, subcoracoid bursitis, long head of biceps synovial sheath, and intra-articular shoulder injection.

Methods: We included 168 participants (66 subacromial-subdeltoid bursitis, 52 subcoracoid, 10 with long head of biceps tenosynovitis 38 had adhesive capsulitis and performed intra-articular shoulder injection) half of them were injected by blind technique and the other half were injected under ultrasound guidance. All of them were diagnosed by ultrasound. All were injected with methylprednisolone acetate $40 \mathrm{mg}$ (Solumedrol, Pfizer) + lidocaine hydrochloride 1\% (Xylocaine Astra Zeneca), $2 \mathrm{ml}$. SPADI score and range of motion were performed before injection and immediately after the injection, after 2 weeks, and after 4 weeks. Further, complications were recorded immediately after the injection, after 2 weeks, and after 4 weeks.

Results: The mean age of the study group was around 35.5 years, with no significant difference between the two groups, with slightly male predominance $(60.7 \%)$. The mean SPADI score was similar between the groups before injection, but the improvement was higher among ultrasound-guided group compared to anatomical landmark-guided group, as showed by the significant difference between the two groups regarding SPADI scores at 2 and 4 weeks post-injection. Regarding the improvement of the range of motion, the ultrasound-guided group showed significantly better improvement compared to the anatomical landmark-guided one all over the 4-week course of follow up. The complication rate was slightly higher among the landmark-guided group, but with non-significant difference (Table 1). The difference between the two groups was highest among adhesive capsulitis cases with intra-articular injection.

Conclusion: Ultrasound-guided injections showed better outcomes for all the 4 injections, especially for intra-articular injection, in addition, it showed a significantly less complications than blind injection.

\section{REFERENCES:}

[1] Elsaman A, Hamed A, Radwan A. Ultrasound-guided epidural block in axia spondyloarthritis patients with limited spine mobility: a randomized controlled trial. The Korean Journal of Pain 2021; 34: 114.

[2] Elsaman AM, Mostafa ES, Radwan AR. Ankle Evaluation in Active Rheumatoid Arthritis by Ultrasound: A Cross-Sectional Study. Ultrasound in medicine \& biology 2017; 43: 2806-13.

Table 1. Comparison between the two groups

\begin{tabular}{|c|c|c|c|c|}
\hline & & $\begin{array}{l}\text { Ultrasound } \\
\text { - guided } \\
(n=84)\end{array}$ & $\begin{array}{l}\text { Anatomic land- } \\
\text { mark - guided } \\
\quad(n=84)\end{array}$ & $P$ value \\
\hline Age & & $35.4 \pm 9.5$ & $36.0 \pm 9.5$ & 0.643 \\
\hline \multirow[t]{2}{*}{ Sex } & Male & $49(58.3 \%)$ & $53(63.1 \%)$ & 0.527 \\
\hline & Female & $35(41.7 \%)$ & $31(36.9 \%)$ & \\
\hline \multirow[t]{4}{*}{ Site } & $\begin{array}{c}\text { Subacromial- } \\
\text { subdeltoid } \\
\text { bursitis }\end{array}$ & $33(39.3 \%)$ & $33(39.3 \%)$ & 0.998 \\
\hline & Subcoracoid & $26(31 \%)$ & $27(32.1 \%)$ & \\
\hline & $\begin{array}{c}\text { Long head of biceps } \\
\text { tenosynovitis }\end{array}$ & $5(6 \%)$ & $5(6 \%)$ & \\
\hline & Adhesive capsulitis & $20(23.8 \%)$ & $19(22.6 \%)$ & \\
\hline \multirow[t]{4}{*}{ SPADI score } & Pre-injection & $55.8 \pm 9.4$ & $54.7 \pm 10.1$ & 0.466 \\
\hline & $\begin{array}{l}\text { Immediately } \\
\text { post-injection }\end{array}$ & $48.6 \pm 8.2$ & $51.2 \pm 8.9$ & 0.051 \\
\hline & $\begin{array}{l}2 \text { weeks } \\
\text { post-injection }\end{array}$ & $44.9 \pm 10.1$ & $49.6 \pm 9.3$ & 0.002 \\
\hline & $\begin{array}{l}4 \text { weeks } \\
\text { post-injection }\end{array}$ & $42.4 \pm 9.7$ & $47.6 \pm 7.8$ & 0.001 \\
\hline \multirow{3}{*}{$\begin{array}{l}\text { Range of motion } \\
\text { improvement } \\
\text { (percent) }\end{array}$} & $\begin{array}{l}\text { Immediately } \\
\text { post-injection }\end{array}$ & $33.6 \pm 9.7 \%$ & $29.4 \pm 11.2 \%$ & 0.010 \\
\hline & $\begin{array}{l}2 \text { weeks } \\
\text { post-injection }\end{array}$ & $37.2 \pm 8.5 \%$ & $32.7 \pm 9.9 \%$ & 0.002 \\
\hline & $\begin{array}{l}4 \text { weeks } \\
\text { post-injection }\end{array}$ & $40.1 \pm 7.3 \%$ & $33.6 \pm 8.3 \%$ & $<0.001$ \\
\hline \multirow[t]{3}{*}{ Complications } & Pain & $12(14.3 \%)$ & $19(22.6 \%)$ & 0.164 \\
\hline & Bleeding & $3(3.6 \%)$ & $8(9.5 \%)$ & 0.119 \\
\hline & Vasovagal attack & $4(4.8 \%)$ & $3(3.6 \%)$ & 0.699 \\
\hline
\end{tabular}

Disclosure of Interests: None declared

DOI: 10.1136/annrheumdis-2021-eular.1908 